\title{
Wandering liver: an unusual cause of recurrent gastric outlet obstruction
}

\author{
Pith Soh Beh, ${ }^{\oplus}$ Adele Burgess, Mithra Sritharan, Jonathan Fong
}

Department of Surgery, Austin Health, Heidelberg, Victoria, Australia

Correspondence to Dr Pith Soh Beh, pithsoh.beh@gmail.com

Accepted 15 February 2019

\section{DESCRIPTION}

A 40-year-old man with a history of cerebral palsy presented to the emergency department with recurrent episodes of vomiting. He had several similar presentations requiring hospital admission over the past 3 years. In 2017, he was admitted for a similar presentation, and CT radiograph demonstrated intestinal obstruction at the proximal jejunal region. He underwent a diagnostic laparoscopy, and a paraduodenal hernia was found. A laparoscopic repair was performed, his symptoms resolved for a short period of time.

However, after 3 months, his symptoms reoccurred and during multiple presentations a number of CT radiographs were performed. Each CT showed the position of his liver in different locations (figure 1), confirming the diagnosis of a wandering liver.

Extrinsic compression of duodenum secondary to the wandering liver was suspected. An upper gastrointestinal gastrograffin fluoroscopy with dynamic positioning of the patient was performed. An ultrasound was also performed during the gastrograffin fluoroscopy study to confirm the position of liver during positioning.

When the patient was in right decubitus position, an ultrasound was performed to confirm that the liver was on the right of midline. Contrast was

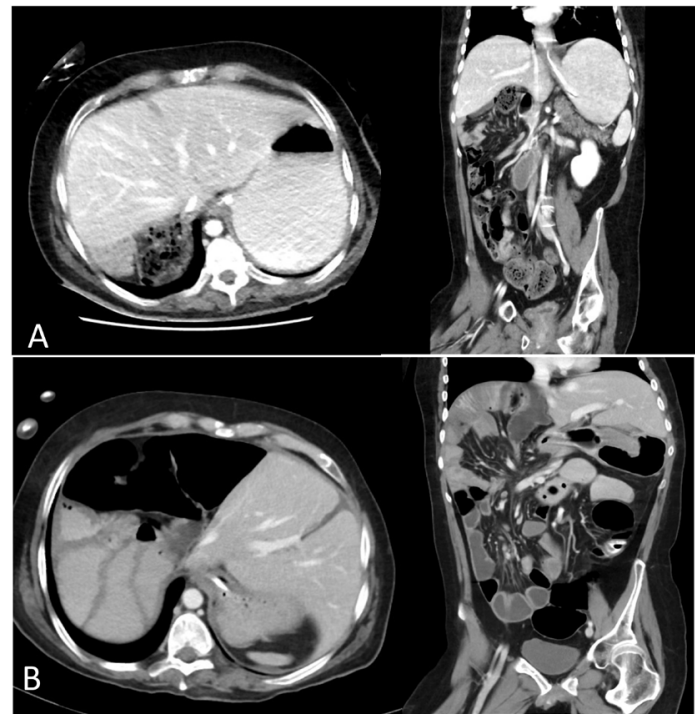

Figure 1 CT radiographs showing liver in different positions. Liver was in its normal anatomical position on the right side of abdomen (A) compared with a wandering liver which has moved to the left side of the abdomen (B).

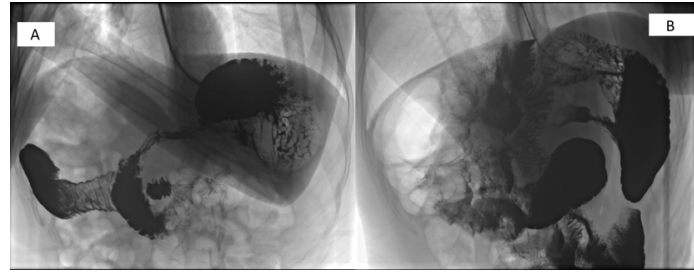

Figure 2 Gastrograffin fluoroscopy study; patient lying on right side $(A)$ and left side $(B)$.

then administered via a nasogastric (NG) tube. The study demonstrated brisk transit. The patient was subsequently repositioned in left decubitus position, and further contrast was administered. This study showed delay in gastric emptying as evidenced by pooling of contrast material in gastric antrum due to extrinsic compression from a wandering liver (figure 2).

The patient's symptoms improved with gastric decompression via NG tube. Oral nutrition was well tolerated, and the patient was discharged home shortly afterwards.

\section{Learning points}

Wandering liver or hepatic vagrancy is a rare condition - only 25 reported cases since 1890. ${ }^{1-3}$

- Most reported cases were associated with colonic, predominantly sigmoid, obstruction or volvulus. ${ }^{4}$

- Due to its rarity and non-specific presentation, diagnosis and management of wandering liver remained challenging. ${ }^{2356}$ However, there were two general approaches in treating patients with wandering liver:

i. For patients with none or mild symptoms, a non-operative approach, such as patient positioning or abdominal wall support, should be considered. ${ }^{27}$

ii. For patients with signs of gastrointestinal obstruction, surgical intervention, such as laparoscopic hepatopexy, is suggested. ${ }^{2-46}$

Contributors $\mathrm{PSB}, \mathrm{JF}$ and $\mathrm{AB}$ treated the patient. MS was consulted for hepatobiliary surgery opinion.

Funding The authors have not declared a specific grant for this research from any funding agency in the public, commercial or not-for-profit sectors.

Competing interests None declared.

Patient consent for publication Obtained. 
Images in...

Provenance and peer review Not commissioned; externally peer reviewed.

\section{REFERENCES}

1 Nichols BW, Figarola MS, Standley TB. A wandering liver. Pediatr Radiol 2010;40:1443-5.

2 Svensson JF, Schlinzig T, Kaiser S. "Wandering liver" in a neonate: case report and review of the literature. J Pediatr Surg 2010;45:635-8.
3 Bauones S, Hoang $\mathrm{H}$, Roman C, et al. Wandering liver: ultrasound and magnetic resonance imaging diagnosis. J Pediatr Surg 2012;47:e21-e25.

4 Rabie MA, Godavitarne C. A wandering folded liver displaced by the distended bowel: a new case report with review of the literature. Acta Chir Belg 2017;117:319-23.

5 Matarazzo L, Mazzocco M, Gioachin A, et al. Wandering Liver, Wondering Doctors! . Pediatr 2018;202:326

6 Parolini F, Alberti D, liver WSurgery 2017:161:1174-5.

7 Grayson RR. Wandering liver and tachycardia. Am Heart J 1958;55:252-4.

Copyright 2019 BMJ Publishing Group. All rights reserved. For permission to reuse any of this content visit

https://www.bmj.com/company/products-services/rights-and-licensing/permissions/

BMJ Case Report Fellows may re-use this article for personal use and teaching without any further permission.

Become a Fellow of BMJ Case Reports today and you can:

- Submit as many cases as you like

- Enjoy fast sympathetic peer review and rapid publication of accepted articles

- Access all the published articles

Re-use any of the published material for personal use and teaching without further permission

For information on Institutional Fellowships contact consortiasales@bmjgroup.com

Visit casereports.bmj.com for more articles like this and to become a Fellow 